\title{
Rethinking of the Crisis of Universalism: Toward a Pluralistic Orientation of Cosmopolitanism
}

\author{
WANG NING
}

\begin{abstract}
In commemorating the centenary of the end of World War I, we could not but reflect on many of the valuable legacies and lessons the War has left behind it. To us humanities scholars, what we are most concerned about is the legitimacy of universalism or whether there is such a thing as absolute universalism. The same is true of modernity, for people may well think that modernity represents the great interest of all people in the world. But modernity manifests itself in different modes in different countries and nations as different countries and nations have different conditions, especially in such an ancient country as China. The present article will illustrate how modernity was imported from the West into China and how it has been readjusted according to its own condition and thereby developing in an uneven way. Through some theoretical elaboration the article has deconstructed the so-called "singular" or "universalist" modernity with the Chinese practice and reconsidered the concept of cosmopolitanism which has certain parallel elements in ancient Chinese philosophy. Considering the pluralistic orientation of contemporary cosmopolitanism, the author offers his own reconstruction of a sort of new cosmopolitanism in the era of globalization.
\end{abstract}

Keywords: universalism; World War I; globalization; modernity; cosmopolitanism; Chinese practice

In 2014, in many parts of the world, people commemorated the centenary of the outbreak of the First World War. Then, in 2018, people once again commemorated the centenary of the end of this world war. Undoubtedly this historical event should be commemorated, for it caused huge disaster to all of mankind and has left behind it many valuable legacies and lessons. We Chinese scholars also pay considerable attention to this significant event although China did not suffer very much from the First World War. What we are most concerned about, however, is the legitimacy of universalism or whether there is such a thing as absolute universalism. When we talk about universalism, we will immediately touch upon the topic of modernity, especially that in 
Rethinking of the Crisis of Universalism: Toward a Pluralistic Orientation of Cosmopolitanism

the Chinese context. As we know, modernity represents the great interest of all the people in the world. But modernity also manifests itself in different modes in different countries and nations as different countries and nations have different conditions. In this essay, I will illustrate China as an example to show how modernity was imported from the West and how it has been readjusted according to its own condition and thereby developing in an uneven way. I will try to prove that since modernity in China is a sort of alternative one which on the one hand has contributed to the grand narrative of global modernity, but on the other hand, deconstructed the so-called "singular" or "universalist" modernity. The same is true of cosmopolitanism which is obviously a Western concept but with which there were certain parallel elements in ancient Chinese philosophy. Considering the pluralistic orientation of contemporary cosmopolitanism, I will offer my own reconstruction of a sort of new cosmopolitanism in the era of globalization.

\section{Why Should We Commemorate the First World War Today?}

As we know, the First World War broke out in 1914 and ended in 1918, as a direct consequence of the political and military struggle chiefly between two major European imperial powers: the British Empire and the German Empire. Along with the progress of the war, more and more countries from Europe, North America and Asia were involved in this worldwide war. It consequently brought about a tremendous disaster to people involved in it and the established world order. The trauma impressed deep in people's memory was later vividly described by quite a few writers in their literary works about the war, such as Earnest Hemingway's The Sun Also Rises (1926) and A Farewell to Arms (1929), William Faulkner's Soldiers' Pay (1926), Scott Fitzgerald's This Side of Paradise (1920), and T.S. Eliot's The Waste Land (1922), to name just a few. In these works, the writers either directly describe the huge disaster brought to people's life and the trauma that remains in people's spirit and memory or portray some characters of the so-called "lost generation" that appeared after the war. Since literature is produced for human beings, it should also write about the sorrow and happiness, separations and reunions of ordinary people. They teach people to love peace and hate wars while seeking eternal happiness. But history cannot repeat itself truthfully, for it can only repeat itself in an allegorical or aesthetic way. That is why we can only read about the war and its consequence chiefly from historical documents and literary works. But these historical documents are undoubtedly selected by those who are in power, and literary works are produced in an allegorical and aesthetic way. But on the other hand, these 
writings just teach people a lesson and warn people that such a human disaster caused by the war should never appear again so that people in the world could live peacefully. They also tell us that there is no such thing as the universally recognized value. We could imagine that during those years of the war, a lot of American young people, encouraged by the so-called "justice, honor and patriotism" promoted by their government, went to the battlefield, only to find the killing of numerous innocent soldiers and more civilians. Today, we live in a peaceful and comfortable environment, but we should remember that there is no such thing as the so-called universally recognized mode of development, for each country should follow its own mode of development so that it will modernize itself both economically and culturally.

From today's point of view, we could re-examine the consequences of the war in a more objective way, for it has after all brought to us both negative and positive experience. As we know, due to the First World War, the British Empire was largely weakened with numerous former colonies becoming independent, and the German Empire was severely defeated but later grew even more powerful and aggressive with the Nazis coming to power. A bit over twenty years later, the Second World War broke out, and people suffered much more from it than from the previous war. After the Second World War, those formerly powerful European empires, such as Britain, France and Germany were almost paralyzed economically with their political influence made much smaller. On the other hand, the United States rose as the first superpower in the world, and there even appeared the two big military camps opposed to each other: the North Atlantic Treaty Organization (NATO) headed by the United States and the Warsaw Treaty Organization headed by the former Soviet Union which was dissolved along with the end of the "Cold War" and disappearance of the USSR in 1991. Obviously, the two world wars have left behind them such a deep trauma in people's memory that they hate any war and hope for eternal world peace. So, it is not surprising that peace and development have always been two major tasks before people of all countries. The governments and people of all countries know that it is all the more necessary to develop themselves politically, economically and militarily so that they could resist any possible war and maintain world peace. Even though there has never appeared any large-scale world war since 1945, regional conflicts and wars have never stopped, such as the Korean War, the Vietnam War and the Gulf Wars which have all caused numerous killings and huge damages. Sometimes, especially during the first and second Gulf War, national sovereignty was severely trodden down and basic human rights were flagrantly abused, let alone huge loss in the world economy. As scholars engaged in war studies, we often ask 
Rethinking of the Crisis of Universalism: Toward a Pluralistic Orientation of Cosmopolitanism

ourselves: Since every country has its own justified reasons when fighting against another country, can we find some justice universally recognized by all countries? Can we think of others when we want to gain our own interest? These things are easily said but difficult to do, for every country has its own justified reasons of maintaining national sovereignty and unique mode of developing itself. Sometimes their success is achieved at the sacrifice of another or other countries. Even the project of modernity manifests itself differently in different countries. Thus, what we should do is to respect others and learn from others since we all live in one world. The recent rise of cosmopolitanism probably represents people's common expectation and good wishes. As for this, I will discuss it later on.

If we say that there are lots of valuable legacies left behind by the two world wars, then I should say that China, in suffering a great deal from the wars, especially from the Second World War, has, on the other hand, changed the unfavorable situation to a favorable situation, so it has also more or less benefited from the two world wars: During the First World War there appeared the New Culture Movement, in which modern sciences and technologies as well as democracy were introduced from the West to China, and China started the process of changing itself from a totalitarian feudal country to a relatively modern democratic country. It was a significant event that the Chinese Communist Party was founded in 1921 when the New Culture Movement reached its high tide. And during the Second World War, in fighting against the Japanese invaders, the CCP could largely develop itself with its armed forces becoming much more powerful, based on which it finally defeated the Chiang Kai-shek regime and founded the People's Republic of China not long after the end of the War. Today, we could only read about the war in historical documents and literary works with the latter more unforgettable, especially those describing Chinese people's resistance against Japanese invasion. Many of these works either eulogize the heroic deeds of the Chinese people and soldiers in their fight against the Japanese invaders or describe the tragic fate of ordinary people suffering in the war. In this sense, when we commemorate the centenary of the First World War, we are actually reflecting on the bitter past history and pointing to a bright future. This is perhaps the very significance why we should commemorate the centenary of the war in such an age of globalization. 


\section{Universal Modernity or Alternative Modernity?}

After the First World War, more and more countries and nations have realized that it is necessary and even urgent to modernize their countries so that they could become powerful enough to resist any possible aggression and avoid any kind of wars. The same is true of China which is regarded as a semi-colonial and semi-feudal country with quite a few concessions within the Chinese territories established by various powers. In order for China to become really independent and flourishing, Chinese intellectuals were always active at the forefront of Chinese modernity, launching large-scale translation of Western science and technology as well as cultural and academic thoughts for the purpose of learning from all the advanced countries and building China into a powerful modernized country. Today, in commemorating the centenary of the First World War, what we Chinese humanities scholars are chiefly concerned with is how such modernity has been metamorphosed through translation and the practice in the Chinese context and how different modernity or modernities appear in those non-Western countries. Although such terms as modernity and modernism are no longer new topics in the Western context, they are still attractive to Chinese humanities scholars, especially those of literary and cultural studies. Following some of my Western colleagues such as Fredric Jameson, Terry Eagleton and Matei Calinescu, who have published extensively on the issue of modernity with regard to postmodernism and who are largely quoted and discussed in the Chinese context, I will mainly deal with the controversial issue from the perspectives of literature and culture, or more specifically, from a Chinese literary and cultural perspective. Unlike the Western scholars above, I will chiefly rely on the Chinese experiences and examples taken from Chinese literature and culture from an international and comparative perspective.

As compared with Chinese intellectuals' enthusiastic translation and critical and creative reception of Western literature and cultural theories in China, modern Chinese literature and culture are little known to scholars and ordinary readers outside of China, especially in the West. In speaking of China's modernity or modernism, one might well think that it is to a large extent translated or imported from the West. So, it is mainly a "translated" theoretical concept. This affirmation is undoubtedly both right and wrong. It is true that modern Chinese culture and literature are deeply influenced by Western culture and literature, but they are also, in receiving Western influence, attempting a dialogue with mainstream world culture and literature in their "glocalized" practice. That is why, Lu Xun, a leading Chinese literary 
Rethinking of the Crisis of Universalism: Toward a Pluralistic Orientation of Cosmopolitanism

and intellectual figure, who always stood at the forefront of China's cultural and literary modernity, called for a sort of "grabbism" (nalai zhuyi). That is, to grab everything useful to China's literary and cultural modernity and social transformation. Because of China's long-standing isolation from the outside world and its conservative attitude to foreign influences, classical Chinese literature developed almost cut off from Western influence. In contrast, the unique tradition of modern Chinese literature was forged directly under the Western influence. One cannot avoid mentioning its existence when dealing with global modernity and world literature, for modern Chinese literature widely participates in the metamorphosed and "glocalized" practice of global modernity. As a result, different versions of modernity have been produced in China. They constitute a sort of alternative modernity or modernities of Chinese characteristics which have both enriched global modernity and deconstructed the "grand narrative" of "singular" modernity dominated by Western culture and ideology. ${ }^{1}$

Upon entering the $20^{\text {th }}$ century, Chinese literary scholars increasingly acknowledged the "marginalized" position of its literature in the broad context of world literature although it did have a long splendid tradition and grand cultural heritage in history. Scholars felt that in order to regain its past grandeur and move from the periphery to the center their literature should be identified with a prior dominant force: Western cultural modernity or modern Western literature and art. That is why these scholars strongly supported the widespread translation of Western literary works along with cultural and academic reflections on this practice as the best way for China to emerge from its state of isolation.

As we know, modernity has always been a heatedly discussed or even debated theoretic topic in China's academic circles with regard to the question of modernism and later that of postmodernism, especially in literary and cultural studies, throughout the $20^{\text {th }}$ century. In this aspect, such Western thinkers or theorists as Jürgen Habermas, Jean-François Lyotard, Jean Baudrillard and Fredric Jameson and their theoretical doctrines are frequently quoted and discussed in the Chinese context, especially when dealing with a sort of postmodern modernity in the present era. Furthermore, Chinese intellectuals think that their theoretical doctrines are universally recognized as correct in the Western context. But in explaining the Chinese condition with their theoretical doctrines, we easily find that they are not universally valid and

As for descriptions and elaborations of the so-called Chinese modernity, see Wang 2012a, 2012b. 
should thereby be modified and even contextualized according to the concrete Chinese practice. Since Jameson's close relations with Chinese academia and his description or critique of modernity with regard to postmodernity and postmodernism is most influential and controversial in China, I will in this part discuss a bit more his idea of "singular modernity" as a particular case.

In the book Singular Modernity: Essay on the Ontology of the Present (2002), Jameson tries to construct and critique a sort of singular modernity, chiefly in the Western context, but in the process of which he has already deconstructed this seemingly grand narrative. To him, there are four theses of modernity:

1. One cannot not periodize.

2. Modernity is not a concept but rather a narrative category.

3. The one way not to narrate it is via subjectivity (thesis: subjectivity is unrepresentable).

Only situations of modernity can be narrated.

4. No "theory" of modernity makes sense today unless it comes to terms with the hypothesis of a postmodern break with the modern. (Jameson 2002: 94)

When Jameson tried to elaborate his four theses of modernity by promoting his book mentioned above in China in summer 2002, it aroused severe debates within Chinese critical circles due more or less to the mistranslation or misunderstanding of his ideas. But to my understanding, he does not want to expand the usage of modernity, but rather, he intends to restrict it to "its aesthetic category or adaptation, which necessarily posits an experience of the work in the present, no matter what its historical origins." (Ibid. 94-95) In this way, he would rather regard it as a "narrative category" renewed in the postmodern era than merely a theoretic "concept", for a category should not necessarily be "fixed" in meaning. It could be modified according to the "glocalized" practice in a country or nation like China.

In this respect, Jameson, is obviously inspired by Lyotard, who thinks that the postmodern is "undoubtedly a part of the modern", and a "work can become modern only if it is first postmodern. Postmodernism thus understood is not modernism at its end but in the nascent state, and this state is constant." (Lyotard 1984: 79) He tries to stimulate the almost emaciated theoretic debate on postmodernism endowing it with a new and continued life. It is very clear that Lyotard, in constructing an inclusive grand narrative of modernity, has already deconstructed its fixed universal meaning and deterritorialized its narrow domain.

The same is almost true of Jameson. For he also puts it in the preface to his book: 
Rethinking of the Crisis of Universalism: Toward a Pluralistic Orientation of Cosmopolitanism

The revival of the concept of modernity is an attempt to solve that problem: in a situation in which modernization, socialism, industrialization (particularly the former, pre-computerized kind of heavy industry), Postmodernism, and the "rape of nature" generally, have been discredited, you can still suggest that the so-called under-developed countries might want to look forward to simple "modernity" itself. (Jameson 2002: 8)

That is, the existence of modernity should depend on different situations, especially in those under-developed or developing countries where modern elements are often mixed up with pre-modern ones and where there might be postmodern elements in some newly developed regions, such as the BRICS countries. Some Western sinologists, through close observations and careful studies, think that it is really a miracle to enable China, "one of the globe's poorest countries" before its economic reform and opening up, to "become a booming economy--- second biggest in the world" (Perry 2014: 5) in the present century. Therefore, they must have their own unique mode of modernity and way of development. In this sense, there should be no such thing as the socalled "singular" modernity as modernity always manifests itself differently in different times and places and should thereby be expressed in plural forms now and then. The practice of the modernity project in the Chinese context has actually helped form a sort of China mode of development, or a Chinese modernity, which is an alternative modernity. Lisa Rofel, in describing a sort of "other modernities" with China as the particular case from an anthropological perspective, points out,

These other modernities are neither merely local enactments nor simply examples of a universal model. They are forced cross-cultural translations of various projects of science and management called modernity. (Rofel 1999: xii)

She is certainly right in dealing with the Chinese case from a perspective of gender studies. I here also take China for example from other perspectives. The modernity we are discussing in the global postmodern era is no doubt different from the one that those Chinese intellectuals advocated in the New Culture Movement in the 1920s in which Lu Xun was writing and the most demanding thing for the country is to modernize itself so that it would catch up with the advanced scientific and cultural trends in those developed countries. With reference to the development of global modernities in different parts of the world, we could affirm that modernity in China is a "translated" or "imported" theoretic concept or a cultural and literary discourse from the West that has been metamorphosed and subject to various constructions and 
reconstructions. When we talk about global modernity today, we are actually dealing with both modernity and postmodernity in the age of globalization, for even such a global modernity must still be localized in a particular cultural context while it travels. In this sense, Chinese (alternative) modernity or modernities have finally become involved in the grand discourses of global modernity and inserted in it some Chinese experiences and elements.

As we might agree that there is indeed such a thing as Chinese modernity, as an alternative modernity among global modernity or modernities, what are characteristics of this alternative (Chinese) modernity? To my preliminary observation, I think there are at least four characteristics of the alternative (Chinese) modernity or modernities, as follows.

First, it is both centripetal and centrifugal. As compared with the fragmentary status of postmodernity, modernity might be "grand" and centralized, characterized by Western-centrism. But since modernity is also viewed as a "universal" standard, it should move or travel from center to periphery and function both at the center as well as at the periphery. It is thereby both centralizing and decentralizing, or both territorializing and deterritorializing with the monolithic center split into pluralistic centers. That is, there might be two types of modernity: a singular modernity in its global sense, and different multiple modernities practiced in different countries or regions. The former is an ideal type of modernity universally recognized in general and the second appeals to particular practices of modernity in different countries or regions. No doubt Chinese modernity comes from global modernity, but it is also practiced in its own way different from Western modernity although it still sticks to the grand label of "modernity". It has actually been "Sinicized" in its practice.

Second, it is both modern and postmodern, and sometimes even premodern. Since China is one of the largest countries with the biggest population in the world, it has been developing in an uneven way. Thus China has its own unique mode of development, or the so-called China Mode (zhongguo moshi). In Beijing, Shanghai, Guangzhou, Shenzhen and other coastal cities, postmodern symptoms appear as if they were Western developed metropolises. They are almost completely manipulated by a sort of (socialist) market economy, which finds particular embodiment in the recent stock market crash in China as the country has completely been involved in the process of globalization and closely connected to world economy. But many of the medium sized cities in the interior part of the country are still modernizing themselves toward a real modernity. So modernity is still an incomplete project, both economically and culturally. 
Rethinking of the Crisis of Universalism: Toward a Pluralistic Orientation of Cosmopolitanism

Third, it is both constructive and deconstructive. Since the cultural soil of China is very poor for modernity to settle down, it is still under construction. But on the other hand, the construction of Chinese modernity has proved that there is no such thing as the so-called "singular modernity" unless it deconstructs the temporary and spatial limitation. The practice of Chinese modernity in the past decades has deconstructed the totalitarian grand discourse of singular modernity paving the way for an alternative modernity or modernities of the Chinese type to appear in the eastern part of the world. It is mixed up with both the Sinicized Marxist doctrines and the reconstructed Neo-Confucianist doctrines. Thus, the achievements made by Chinese intellectuals in the process of modernity will in turn contribute a lot to the grand and universal narrative discourse of global modernity if there were indeed one.

Fourth, it is both global and local, or simply called "glocal". It is true that the advent of globalization has enabled China to change rapidly in an overall way, and the country is one of the very few in the world that directly benefits a great deal from the process of globalization. Or, according to Japanese American thinker Francis Fukuyama, China is one of the biggest winners of globalization, ${ }^{2}$ not only economically but also politically and culturally as it has already formed a unique mode of development: the China Mode. But as we all know, globalization cannot be realized unless it is localized in a particular (Chinese) cultural soil. Economically speaking, China should observe the various regulations of the WTO and other international organizations, but politically and culturally, it still has its own stubborn and unique tradition and condition. In this way, a "glocalized" practice of modernity is both possible and justified. ${ }^{3}$

Judging by this, we could reach a tentative conclusion: anything universal should be readjusted according to given conditions and different practices and finally particularized if it should be practiced effectively. The same is true of cosmopolitanism which I will discuss in the last part of my essay.

\section{Toward a Pluralistic Orientation of Cosmopolitanism}

Cosmopolitanism (shijie zhuyi) is not an unfamiliar concept in the history of Chinese philosophy and intellectual thought as it has some parallel elements in ancient Chinese people's world view (tianxia guan). In commemorating

2 Cf. Fukuyama 2011.

3 Cf. Wang 2015. 
the centenary of the First World War, we could not but think of the theoretic doctrine of cosmopolitanism and the cosmopolitan trend which was popular round the years of the War. Later, due to the rise of the irresistible trend of national independence, cosmopolitanism gradually faded before having a considerable influence. The same is almost true of China, where there rose for a while a trend of cosmopolitanism among some radical revolutionaries and avant-garde intellectuals. Such eminent figures as Li Dazhao, Cai Yuanpei, Hu Shi, Zheng Zhenduo and Ba Jin were more or less involved in this movement. $\mathrm{Ba}$ Jin and another Chinese novelist and translator Ye Junjian even tried to study Esperanto in an attempt to promote their writings in the world. But unfortunately, Ba Jin immediately recognized that the artificial language could by no means be compared with the popularity and effectiveness of English. Thus, he still kept writing in his mother tongue Chinese while Ye wrote in the artificial language. Ironically speaking, Ba Jin's works, largely through translations done by overseas translators, have been much more popular and influential than Ye's.

But after all, the advent of cosmopolitanism in early $20^{\text {th }}$-century China indeed affected quite a few important political and intellectual figures. During the high tide of cosmopolitanism in China, even Dr. Sun Yat-sen, founding leader of the Tung Meng Hui (Chinese Revolutionary League), was attracted by the cosmopolitan trend largely due to his own wide global horizon and diasporic experience abroad, but he soon became calm thinking that the most urgent task for Chinese intellectuals at the time was to seek national independence rather than advocating anything like cosmopolitanism. ${ }^{4}$ To Sun, China was not powerful and qualified enough to talk about cosmopolitanism since the country was both poor and backward. Maybe it could talk about it when China becomes rich and powerful in the future. ${ }^{5}$ So it is not surprising that the cosmopolitan trend finally came to an end in China without any result. Today, in the age of globalization, cosmopolitanism rises again and has become another heatedly debated theoretic topic. Like the theoretic concepts of modernity, postmodernism and globalization, the recent appearance of cosmopolitanism in the West and the rest of the world is by no means accidental. It is largely due to the advent of the era of globalization which paves the way for cosmopolitanism to rise again. Although it first rose in the Western academia in the 1990s, it has actually had a long history, or a sort of

4 As for Sun Yat-sen's interest in and comments on cosmopolitanism in China, cf. Sun Yat-sen 1986: 216-17

5 Ibid. 
Rethinking of the Crisis of Universalism: Toward a Pluralistic Orientation of Cosmopolitanism

"prehistory" from antiquity. It is worth revisiting this concept before offering my reflection on the significance of cosmopolitanism in today's context, especially in contemporary China.

We probably know that as an interdisciplinary theoretical concept and critical discourse, cosmopolitanism could even date back to ancient Greek philosophical thought. What we should state here is that cosmopolitanism is first of all a political philosophical concept, whose ethical coloring is very strong. That is why it is closely related to literature and culture in the current global era. Cosmopolitanism is intended to tell us that all human beings, no matter from what ethnic groups and with what countries or nations they are affiliated, belong to a big single social community. This is very close to the current construction of the discourse of globalization, according to which people all share a fundamental ethic and right transcending over individual nations or countries. This "imaginary" community should be cultivated so as to represent a sort of universal value recognized by all human beings.

However, according to Craig Calhoun, cosmopolitanism today has a different meaning on different occasions. It is true that it refers to the world as a totality rather than individual places or communities (Calhoun 2008), but on the other hand, it also indicates that those holding this belief feel quite at home in a diversified community. That is, different people could get along with each other without giving up their own customs or ways of life. In short, it mainly refers to a man's inclination and endurance in this sense. So this sort of cosmopolitanism crossing the boundary of nation-state is opposite to other terms of strong nationalistic sentiment like patriotism and nationalism. Nowadays we could discuss cosmopolitanism on three levels: the cosmopolitanism on the philosophical level, that on the political and sociological level and that on the cultural and literary level.

As for the philosophical dimension of cosmopolitanism, it dates back to Greek philosopher Diogenes, who was also the first Western philosopher not confining himself to a particular state. He openly declared, "I am a citizen of the world (kosmopolitês)". Since then the "citizen of the world" has become the ideal pursued by all those who have a cosmopolitan belief. Similarly, to these people, to be loyal to entire mankind should not necessarily confine themselves to a particular nation-state. What they pursue is not merely the interest of a particular nation-state, but rather, the universal value and interest of entire mankind.

The Enlightenment period is the one in which cosmopolitanism is highlighted. In 1795, Kant even put forward a sort of cosmopolitan law/right in 
his article "For Perpetual Peace". ${ }^{6}$ But his ideas are challenged by tension in other people who think them not consistent. This is partly due to the tension of the concept cosmopolitanism itself. Furthermore, Kant also introduced a "cosmopolitan law" which is actually the domain of the third public law apart from the constitution and international law. According to this law, people as individuals have all rights as citizens of the earth rather than those of a particular country. Obviously, the "citizen of the earth" comes from the "citizen of the world", except that it is of a broader global concern for everything other than mere human beings. Apparently, as a pioneering figure of the cosmopolitan thought, Kant has ideas that have laid a solid foundation for many of the claims by contemporary cosmopolitan thinkers. So when we discuss the issue of cosmopolitanism today, we usually refer to his early thinking.

Since the discovery of the Americas in 1492 by Christopher Columbus, one of the earliest cosmopolitans in action, the capitalist expansion and swallowing up of weak countries' national industries, along with the formation of a new division of international labor, all these have prepared the way for the process of globalization. In their co-authored Communist Manifesto, Marx and Engels describe the market capitalist practice of breaking the boundary of nationstate and expanding its own forces. As a consequence, the production and consumption are not limited to their own countries, but rather, in the distant countries and even continents. In their eyes, cosmopolitanism is an ideological reflection of capitalism. From today's point of view, we may well come to the conclusion that the contributions made by Marx and Engels not only lie in their discovery of surplus value, but also in their discovery of the regulation of globalization in economy and culture. Their description and discussion have already become important theoretical resources of $20^{\text {th }}$-century political philosophers and literary and cultural scholars in their discussion of the issues of modernity and globalization.

As revolutionary thinkers who had a broad cosmopolitan vision, Marx and Engels not only explored the "cosmopolitan" characteristics of capitalist production, but also thought that the proletarians of various countries shared some fundamental characteristics and common interests. Furthermore, Marx himself was a cosmopolite, and his Jewish ancestry and later communist belief determined that he would certainly travel and settle everywhere as a citizen of the world and work in the interests of all mankind. The "First International" and "Second International" founded under the influence of the Marxian

\footnotetext{
6 As for Kant's project for perpetual peace, cf. Wood 1998.
} 
Rethinking of the Crisis of Universalism: Toward a Pluralistic Orientation of Cosmopolitanism

thought were characterized by his cosmopolitan/ international tendency and political and organizational practice.

Upon entering the $20^{\text {th }}$ century, the process of economic globalization has also speeded the process of globalization in politics and culture. According to Jan Aart Scholte, from the 1960s onward, the use of the term globalization has spread in all the languages, social departments and professionals and academic disciplines. Such terms as globe, global and globalism have already had a long history which could even date back to the Latin word globus. But the term "globalization" that appeared in recent time implies a sort of development, a process, a tendency and a change (cf. Scholte 2007). In this sense, we could say that the phenomenon of globalization has provided cosmopolitanism with necessary soil for its rise, and cosmopolitanism has also provided for globalization a sort of theoretic discourse. Thus, Beck and Grande remind people that we should take into account a process connecting the two. Here he views global connection as a sort of "cosmopolitanization", and cosmopolitanism to him is nothing but a feeling and attitude coming from the ethical responsibility (Beck \& Grande 2007: 5-6).

The founding of some transnational organizations could be viewed as such a practice. For example, the League of Nations and the United Nations founded respectively after the First and Second World Wars are such international organizations of "global governance" although they are almost powerless in dealing with severe regional conflicts and global political affairs. Obviously, these international organizations cannot replace the function of the state, let alone the so-called "world government". Thus, they actually function as a sort of utopian governing organization to many people. And this is why cosmopolitanism on the philosophical and political level is often attacked by its critics.

As for the multi-dimensional orientations and contradictions of cosmopolitanism, Calhoun has pertinently pointed out that in using the concept cosmopolitanism, scholars are often confused and therefore appear inconsistent due to the tension of this controversial term (Calhoun 2008: 431). Obviously, those who are against it think from a political perspective that as far as the nation-state, on which nationalism and patriotism are based, is concerned, cosmopolitanism does not have such a world nation or world government. Therefore, the claim for cosmopolitanism is somewhat meaningless. As the theory of globalization was very influential in the 1980s intellectual circles, scholars once again became interested in the cosmopolitan ideas in Kant's philosophy. However, this new cosmopolitanism has already transcended the old cosmopolitanism on the ethical level and the limits of Kant's legal cosmopolitanism becoming a political and cultural cosmopolitanism. 
WANG

As I have described above, the current prevalence of cosmopolitanism is by no means coincidental. It is closely related to the present international political and economic situation. On the one hand, all countries still maintain their national sovereignty, but on the other hand, they are shedding power to globalization, for they all realize that they are already interrelated and interconnected to each other as if they all lived in a vast "global village" sharing some fundamental common value standards and ethics. As a Chinese scholar of literary and cultural studies who has recently done some research on cosmopolitanism with regard to world literature and published extensively both in English and in Chinese, ${ }^{7}$ I would like here once again to sum up what my international colleagues have already conceptualized and offer my own further construction of cosmopolitanism from a global as well as Chinese perspective. To me, cosmopolitanism could be described in the following ten forms:

(1) As something transcending the nationalist form;

(2) As a pursuit of moral justice;

(3) As a universal human concern;

(4) As a cosmopolitan and even diasporic state;

(5) As something decentralizing and pursuing a pluralistic cultural identity;

(6) As a pursuit of human happiness and cosmopolitan unity;

(7) As a political and religious belief;

(8) As a realization of global governance;

(9) As an artistic and aesthetic pursuit;

(10) As a critical perspective from which to evaluate literary and cultural product.

Of course, this is only my subjective construction based on other people's ready-made research and my dynamic elaboration and reconstruction. What I want to see is more discussion and even debate on this controversial issue so that there will appear a pluralistic orientation of cosmopolitanism. But what will the pluralistic orientation of cosmopolitanism be like? I just want to say a few words before ending this essay.

In my opinion, first of all, cosmopolitanism does not necessarily mean homogenization, especially in speaking of culture. That is, in a cosmopolitan city like New York, Paris, London and Shanghai, there are many different ethnic groups coexisting and learning from each other. They could get along with each other without giving up their own social and cultural conventions and ways of life. Second, cosmopolitanism does not necessarily mean universalism:

For my major English publications, cf. Wang Ning 2010, 2011, 2013, 2014. 
Rethinking of the Crisis of Universalism: Toward a Pluralistic Orientation of Cosmopolitanism

the former refers to a degree of endurance, and the latter appeals to a sort of consensus. Anything that seems universal is actually relative. So, in this sense, any country, be it powerful or weak, and be it Western or Eastern, should be equally treated, and their social convention and cultural tradition should be respected. Third, cosmopolitanism should not necessarily be opposite to patriotism or nationalism, for a person might love both his own motherland as well as the entire world. And good human beings should not only love mankind, but also love every living thing on the earth. So they actually have a sort of relatively universal love and global human concern. Fourth, to call for a sort of cosmopolitanism does not necessarily mean writing off the difference of cultures, for one of the characteristics of cultural globalization is cultural diversity which has already become more and more apparent in the process of globalization. Last but not least: there should be no such thing as a singular cosmopolitanism as it manifests itself in different forms and should thereby develop in a pluralistic orientation. As is well known, classical Chinese philosophy is characterized by seeking harmony but not uniformity. That is, people from different countries could get along harmoniously while keeping their own customs and cultural conventions. This heritage has also been inherited by contemporary Chinese people. As we still remember that in 2008, the main slogan of Beijing Olympic Games was “One World, One Dream”. That is, people of all countries live in one world although in different regions and continents with different cultural conventions and religious beliefs. The same is true of their dream: one common dream of living peacefully and flourishing, although there might be different ways of realizing this dream. American people, for instance, usually realize their American Dream through their selfreliance and hard work so as to achieve individual success; while Chinese people would realize their China Dream by working hard together so as to realize the renaissance of the entire Chinese nation. Judging by this, we could say that if we can think and act according to the above pluralistic cosmopolitan views, our world will avoid conflict and war and maintain eternal peace. The "perpetual peace" advocated by Kant many years ago will most probably be realized. This is perhaps the most valuable legacy of the First World War.

\author{
Wang Ning \\ wangn22@sjtu.edu.cn;wangning@tsinghua.edu.cn \\ Institute of Arts and Humanities \\ Shanghai Jiao Tong University \\ 800 Dongchuan Road \\ Shanghai 200240 \\ P. R. CHINA
}


WANG

\section{Bibliography}

Beck, U.; Grande, E. 2007. Cosmopolitan Europe. Cambridge: Polity.

Calhoun, C. 2008. Cosmopolitanism and Nationalism. - Nations and Nationalism, 14 (3), 427-48.

Fukuyama 2011 = A Dialogue between Yu Keping and Fukuyama...: The Biggest Challenge Confronting the China Mode of Development. - Beijing Daily, 28.03.

Jameson, F. 2002. A Singular Modernity: Essay on the Ontology of the Present. London and New York: Verso.

Lyotard, J.-F. 1984. The Postmodern Condition: A Report on Knowledge. Transl. by G. Bennington, B. Massumi. Minneapolis: University of Minnesota Press.

Perry, E. J. 2014. Growing Pains: Challenges for a Rising China. - Daedalus, 143 (2), Spring, 5-13.

Rofel, L. 1999. Other Modernities: Gendered Yearnings in China after Socialism. Berkeley, Los Angeles and London: University of California Press.

Scholte, J. A. 2007. Globalization. - R. Robertson, J. A. Scholte, eds., Encyclopedia of Globalization. New York and London: Routledge, Vol. II, 526-32.

Sun Yat-sen. 1986. = Sun Zhongshan quanji [Collected Works of Sun Yat-sen], Vol. 9. Ed. by the Institute of History of Guangdong Academy of Social Sciences. Beijing: Zhonghua shuju.

Wang Ning. 2010. World Literature and the Dynamic Function of Translation. Modern Language Quarterly, Vol. 71, No. 1, 1-14

Wang Ning. 2011. 'Weltliteratur': from a Utopian Imagination to Diversified Forms of World Literatures. - Neohelicon, XXXVIII, 2: 295-306

Wang Ning. 2012a. Translating Modernity and Reconstructing World Literature. Minnesota Review, Vol. 2012, No. 79 (Autumn), 101-112

Wang Ning. 2012b. Multiplied Modernities and Modernisms. - Literature Compass, 9/9, 617-622.

Wang Ning. 2013. Cosmopolitanism, World Literature and Chinese Literary Practice. - The Journal of English Language and Literature, Vol. 59, No. 3 (Summer), 385-398.

Wang Ning. 2014. Cosmopolitanism and the Internationalization of Chinese Literature. - A. Duran, Y. Huang, eds., Mo Yan in Context: Nobel Laureate and Global Storyteller. West Lafayette, Indiana: Purdue University Press, 167-181.

Wang Ning. 2015. Globalisation as Glocalisation in China: A New Perspective. - Third World Quarterly, Vol. 36, No. 11 (2015), 2059-74.

Wood, A. W. 1998. Kant's Project for Perpetual Peace. - P. Cheah, B. Robbins, eds., Cosmopolitics: Thinking and Feeling beyond the Nation. Minneapolis and London: University of Minnesota Press, 59-76. 